\title{
Clinical management of treatment failure in patients with oropharyngeal tularemia: A retrospective evaluation
}

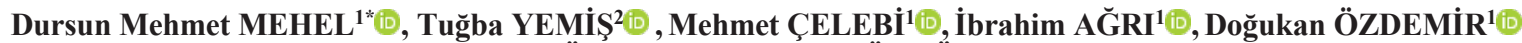 \\ Asude ÜNAL ${ }^{1}$, Abdulkadir ÖZGÜR ${ }^{3}$ (i)
}

\author{
${ }^{1}$ Department of Otorhinolaryngology, Samsun Health Practices and Research Cener, Samsun, Turkey \\ ${ }^{2}$ Department of Otorhinolaryngology, Gümüşhane State Hospital, Gümüşhane, Turkey \\ ${ }^{3}$ Department of Otorhinolaryngology, Faculty of Medicine, Ondokuz Mayis University, Samsun, Turkey
}

\begin{abstract}
\begin{tabular}{cccc}
\hline Received: 11.07 .2020 & $\bullet$ & Accepted/Published Online: 16.01 .2021 & •
\end{tabular}
Abstract

Tularemia is a zoonotic disease caused by Francisella tularensis pathogen. It can be transmitted via wild animals, infected water, and contaminated food. In our study, 13 patients who were admitted to our clinic with a neck mass were retrospectively evaluated for symptoms, findings, diagnosis, applied treatments, and the causes of delay in treatment. The ages of patients diagnosed with tularemia ranged from 19-70 years, with a mean age of 48.5 years. All patients resided in the countryside and all had been repeatedly administered penicillin and macrolide group antibiotics before referral to our clinic. The patients consulted our clinic with a delay of 8 to 30 days (average 11.5 days) after the onset of the first symptom. Six (46.1\%) patients had deep lymphadenopathy, while lymphadenopathy in seven $(53.8 \%)$ was superficial. Suppuration was observed in all adenopathies located superficially to the lymph, while skin fistulization was present in three patients. The diagnosis was made by a serum microagglutination test. Doxycycline, ciprofloxacin, and streptomycin group antibiotics were used in the treatment. No complications due to treatment were observed in the early period. In conclusion; the diagnosis of tularemia is not straightforward at the initial admission of the patients since the symptoms of tonsillopharyngitis, fever, and cervical adenopathy are similar in oropharyngeal tularemia and upper respiratory tract infections. Therefore, the antibiotics administered to the patients are not effective. In endemic regions, tularemia should be considered in the differential diagnosis in patients with tonsillopharyngitis and adenopathy in the neck
\end{abstract}

Keywords: Tularemia, tonsillopharyngitis, treatment, neck adenopathy

\section{Introduction}

Tularemia is a zoonotic disease caused by the pathogen Francisella tularensis, an immobile, aerobic, gram-negative coccobacillus. It is the primary cause of disease in wild rabbits and rodents (Ozel et al., 2010). The causative agent is transmitted to humans through direct contact with infected animals, via vectors such as ticks and flies, by inhalation of infected aerosols, and following the consumption of contaminated food or water. The pathogen is resistant to humid and cold environments but is sensitive to heat and sunlight (Ellis et al., 2002). Depending on the mode of transmission, infection can occur with different clinical features. These include ulceroglandular, glandular, oculoglandular, oropharyngeal, pneumonic, and typhoidal forms of the disease.
In the oropharyngeal type, acute pharyngitis or tonsillopharyngitis is accompanied by cervical adenopathy. Tonsillopharyngitis, herpangina, infectious mononucleosis, adenovirus infection and diphtheria are involved in the differential diagnosis of oropharyngeal tularemia (WHO, 2007). Tularemia outbreaks in our country are reported in Thrace, South Marmara, the Western and Central Black Sea region, and Central Anatolia, and the cases reported are mostly of the oropharyngeal form (Lindquist et al., 2002). The symptoms and findings of oropharyngeal tularemia are similar to those of upper respiratory tract infections (URTIs), the patients generally receive antibiotic treatment for common microorganisms causing URTIs. In those cases, tularemia is 
not considered initially; therefore, the diagnosis and treatment are delayed (Atmaca et al., 2005). Common antibiotic groups effective for tularemia are aminoglycosides, quinolones, and tetracyclines (Kılıç and Yeşilyurt, 2011).

The aim of the present study is to analyze the age, gender, symptoms, clinical and laboratory findings, and treatment protocols of patients diagnosed with tularemia in our clinic and to evaluate the reasons for delays in treatment.

\section{Materials and methods}

The study was granted approval by the ethics committee of our hospital. The study was done in accordance with the Helsinki Declaration. The files of 13 patients diagnosed with tularemia in our clinic between January 2015 and June 2018 were retrospectively analyzed.

The patients referred to our clinic with sore throat, fever, or neck swelling were admitted to the service with a preliminary diagnosis of tularemia. The detailed anamnesis revealed that all patients had received previous treatment for tonsillopharyngitis or cervical lymphadenitis. Full blood exams, biochemistry tests, a serological exam for Salmonella, Brucella, Toxoplasma, rubella, cytomegalovirus (CMV), herpes simplex virus (HSV), Epstein-Barr virus (EBV) and tularemia were performed. Neck ultrasonography and computed tomography was done to investigate the etiology of the neck mass. The sera of the patients were outsourced to the National Tularemia Reference Laboratory at Refik Saydam Public Health Institute for analysis by a microagglutination test (MAT). According to the World Health Organization's tularemia guideline, those with an antibody titer of 1/128 and above in MAT or those with a four-fold or more increase in antibody titer in tests performed two weeks apart were considered positive. Appropriate treatment was initiated in patients whose sera tested positive for tularemia.

The age and gender of the patients diagnosed with tularemia, along with their complaints, the time interval between the onset of complaints and the referral to our clinic, the clinical and laboratory findings, and the treatment administered to the patients were recorded.

\section{Results}

The ages of the 13 patients included in the study ranged from 19-70 years, with an average age of $48.5 \pm 14$ years. Four $(30.7 \%)$ of the patients were male and nine $(69.2 \%)$ were female.

None of the patients had a history of a tick bite or consumption of prey meat. One patient had a history of contact with a mouse, and two patients had consumed water from a well. All cases reported that they resided in rural areas and were engaged in livestock breeding. Eight cases were from the same village, while two cases were from the same family.

The primary complaints of the patients to their physicians were sore throat, fever, and swelling in the neck. Two patients had been administered amoxicillin, seven patients had been given amoxicillin combined with clavulanic acid, and four patients had been given macrolide group antibiotics prior to their tularemia diagnosis. Repeated antibiotic treatments had been administered to four patients whose symptoms had not regressed. The time interval between the onset of patient complaints and their admission to our clinic was between eight and 30 days, with an average of 11.5 days.

The adenopathies in the neck were not suppurated in six patients (46.1\%) (Fig. 1), while in seven patients (53.8\%) they were suppurated (Fig. 2). Among those with suppurated adenopathy, three patients $(23 \%)$ had skin fistulization and discharge (Table 1). In one patient with level II and III adenopathy, computed tomography revealed a $1 \mathrm{X} 1.5 \mathrm{~cm}$ sized parapharyngeal abscess on the same side. No microorganism growth was observed in the puncture sample removed from the abscess showing adenopathy or in culture samples taken from the throat of that patient. All cases were of the oropharyngeal form. The mean leukocyte count was within normal limits $\left(8.44 \pm 3.18\right.$ per $\left.\mathrm{mm}^{2}\right)$, the average erythrocyte sedimentation rate was $59.9 \pm 21.1 \mathrm{~mm}^{3} / \mathrm{h}\left(20-95 \mathrm{~mm}^{3} / \mathrm{h}\right)$, and the average Creactive protein $(\mathrm{CRP})$ values were $2.7 \pm 2.1 \mathrm{mg} / \mathrm{L}(0.5-7.65$ $\mathrm{mg} / \mathrm{L}$ ). Laboratory findings of the patients are shown in Table 2. The first serum samples of four patients were positive for $F$. tularensis MAT at 1/1280 titer, while in one patient, the first sample was negative but the second sample was positive at $1 / 80$ titer (Table 3). Following their tularemia diagnosis, seven patients $(53.8 \%)$ were administered oral doxycycline, four (30.7\%) were administered parenteral-oral ciprofloxacin, and two $(15.4 \%)$ were administered parenteral streptomycin for 10 days. No complications were observed in the early period following treatment.

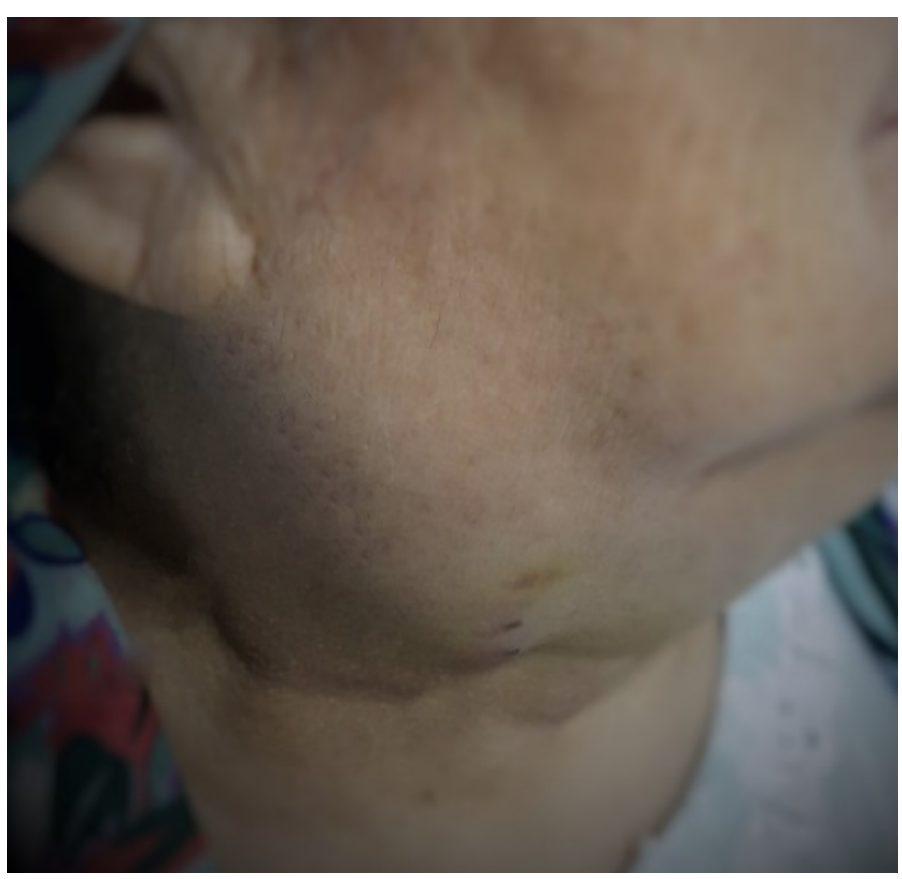

Fig. 1. The patient with non-suppurative lymphadenopathy on the right side of the neck 


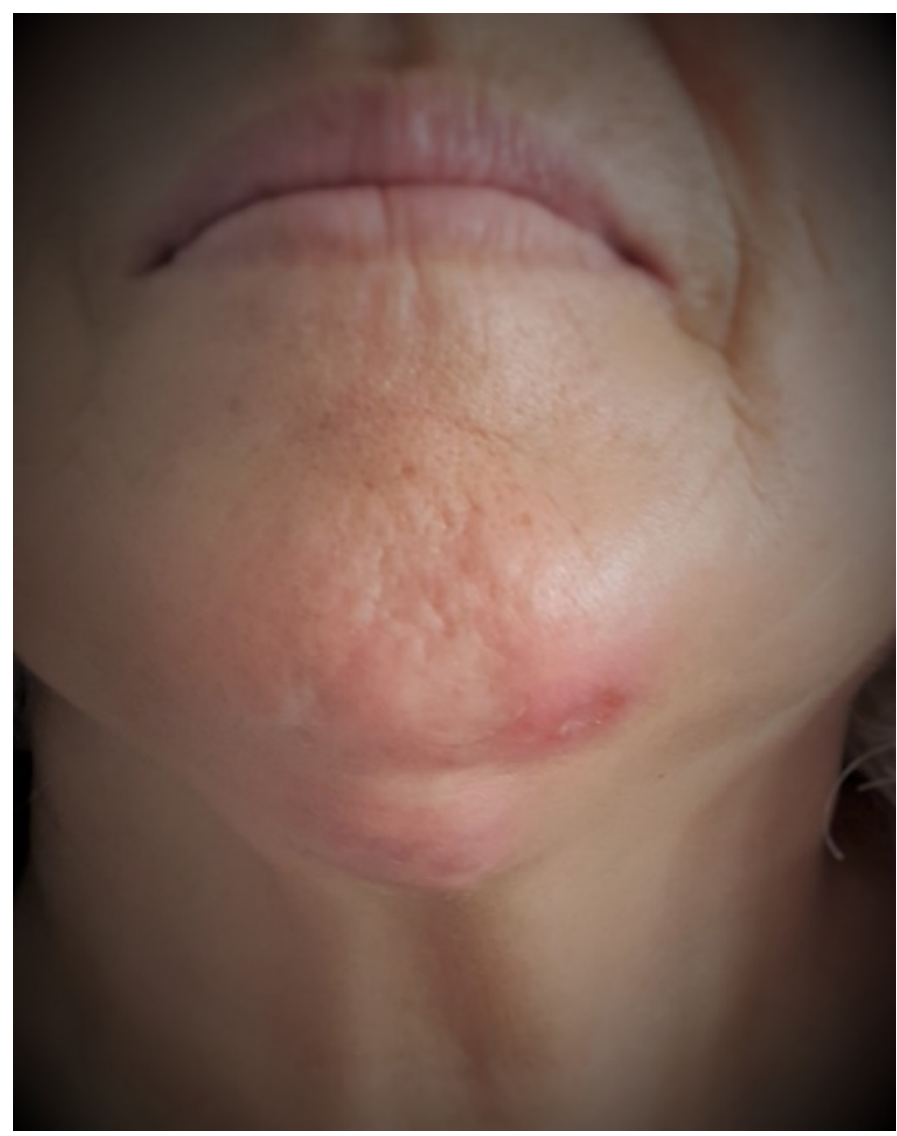

Fig. 2. The patient with suppurative lymphadenopathy in the submental region

Table 1. The localization and features of adenopathies on the neck

\begin{tabular}{|c|c|c|c|c|c|c|}
\hline 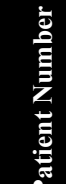 & 馬 & 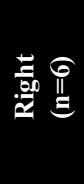 & 元 & 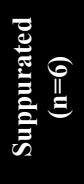 & 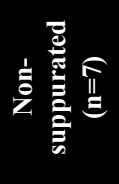 & 苞 \\
\hline 1 & Level IA & - & + & - & + & + \\
\hline 2 & Level IB & + & - & - & + & - \\
\hline 3 & Level IB & + & - & - & + & + \\
\hline 4 & Level IB & - & + & + & - & - \\
\hline 5 & Level IB & - & + & + & - & - \\
\hline 6 & Level II & + & - & + & - & - \\
\hline 7 & $\begin{array}{l}\text { Level II, } \\
\text { III }\end{array}$ & + & - & + & + & - \\
\hline 8 & $\begin{array}{l}\text { Level II, } \\
\text { III }\end{array}$ & + & - & + & - & - \\
\hline 9 & $\begin{array}{l}\text { Level II, } \\
\text { III }\end{array}$ & - & + & + & - & - \\
\hline 10 & Level III & + & - & - & + & - \\
\hline 11 & $\begin{array}{c}\text { Level III, } \\
\text { V }\end{array}$ & - & + & - & + & + \\
\hline 12 & $\begin{array}{l}\text { Parotid } \\
\text { region }\end{array}$ & - & + & - & - & - \\
\hline 13 & $\begin{array}{l}\text { Parotid } \\
\text { region }\end{array}$ & - & + & - & + & - \\
\hline
\end{tabular}

\section{Discussion}

Tularemia is a zoonotic disease that appears epidemic, with seasonal characteristics, in the Black Sea region. In cases without a history of a tick bite or in those seen during winter, water-borne transmission should be considered (Kılıç, 2010). The lack of regular chlorination of spring waters in villages and the history of consumption of well water in some patients also support this idea. Eight of our patients had come from the same village, so the pathogen had quite possibly been transmitted through the common source of water.

Table 2. Laboratory findings of the patients

\begin{tabular}{lccc|}
$\begin{array}{l}\text { Patient } \\
\text { Number }\end{array}$ & $\begin{array}{c}\text { Sedimantation } \\
\text { Rate }\left(\mathbf{m m}^{\mathbf{3}} \mathbf{/ h}\right)\end{array}$ & $\begin{array}{c}\text { C-Reactive } \\
\text { Protein } \\
(\mathbf{m g} / \mathbf{L})\end{array}$ & $\begin{array}{c}\text { Leukocyte } \\
\left(\mathbf{p e r} \mathbf{~ m m} \mathbf{~}^{\mathbf{}}\right)\end{array}$ \\
\hline 1 & 20 & 0.5 & 12.4 \\
2 & 95 & 7.6 & 9.1 \\
3 & 53 & 3.5 & 3.9 \\
4 & 44 & 2.1 & 7.7 \\
5 & 86 & 5.7 & 6.2 \\
6 & 65 & 3.1 & 8.7 \\
7 & 68 & 4.4 & 10.3 \\
8 & 55 & 1.1 & 11.4 \\
9 & 37 & 2.6 & 9.4 \\
10 & 41 & 1.7 & 14.3 \\
11 & 70 & 0.7 & 5.6 \\
12 & 65 & 1.0 & 4.7 \\
13 & 80 & 1.3 & 5.3 \\
\hline
\end{tabular}

Table 3. Microagglutination test (MAT) results of patient sera

\begin{tabular}{|ccc|}
$\begin{array}{c}\text { Number of patients } \\
(\mathbf{n}=\mathbf{1 3})\end{array}$ & $\begin{array}{c}\text { First serum MAT } \\
\text { titer }\end{array}$ & $\begin{array}{c}\text { Second serum } \\
\text { MAT titer }\end{array}$ \\
\hline 4 & $1 / 1280$ & - \\
5 & $1 / 640$ & - \\
1 & $1 / 320$ & - \\
1 & $1 / 160$ & - \\
1 & $1 / 20$ & - \\
1 & - & $1 / 80$ \\
\hline
\end{tabular}

The oropharyngeal form of tularemia is generally localized to the head-neck region, and patients with this form have prominent complaints of sore throat, fever, and mass in the neck (Meriç et al., 2008). A detailed anamnesis must be obtained from patients with neck masses, and they should undergo full physical examinations. The residence, hobbies, and previous infections of the patient (such as tuberculosis etc.) must be questioned (Sencan et al., 2009). The prominent symptoms of oropharyngeal tularemia are the same as those of upper respiratory tract infections; therefore, a differential diagnosis is generally not achieved in outpatient clinics and the patients experience delays in diagnosis and treatment of their tularemia (Helvaci et al., 2000). Literature reports of patients with tularemia generally indicate a history of beta-lactam antibiotic treatment without any improvement in patient symptoms (Sencan et al., 2009; Barut and Çetin, 2009). The patients included in the current study had similarly been administered penicillin or macrolide group antibiotics with an initial diagnosis of tonsillopharyngitis or cervical lymphadenitis before referral to our clinic. These patients who did not improve because of inappropriate treatment were subsequently referred to our clinic with an average delay of 11.5 days after the onset of their initial symptoms. The physical examinations of patients with oropharyngeal tularemia often reveal a unilateral cervical lymphadenopathy in the neck. One 
result of the delay in treatment for tularemia is lymph node suppuration, which is the most common complication, with a rate of 30\% (Helvac1 at al., 2000; Willke, 2006). In our study, adenopathy was present in all cases at levels I, II, III, and V, and $53.8 \%$ of these lymph nodes were suppurated. During the treatment process, three patients $(23 \%)$ had suppurated adenopathy that had fistulized to the skin.

Tularemia diagnosis is generally made by serological tests. The serology results can be negative during the first three weeks of infection in $30 \%$ of patients. Definitive diagnosis can be made by isolation of the pathogen from lymph ganglions, wounds, blood, phlegm, or pleural fluid (Ellis at al., 2002). In the present study, the diagnosis was made by positive serological tests. MAT revealed $F$. tularensis antibody positivity $(\geq 1 / 80)$ in 12 patients. One individual who was a resident of the same household with a patient diagnosed with tularemia was evaluated as a tularemia case and treated accordingly, despite an antibody titer of $1 / 20$, because they had symptoms that did not improve with previous antibiotic treatment.

Chloramphenicol, tetracyclines, and aminoglycosides are used for the tularemia treatment and combination therapy is administrated as well. Recent studies report that quinolones, and especially ciprofloxacin, can also be used successfully in the treatment. Quinolones are bactericidal, less toxic than aminoglycosides, and easier to use (Tarnvik and Chu, 2007; Hepburn and Simpson, 2008). A study conducted by Meriç et al. on 145 oropharyngeal tularemia cases from Turkey reported that treatment failure was more common in their group receiving tetracycline, while treatment in their quinolone group was as successful as treatment in their aminoglycoside group (Meriç et al., 2008). Hepburn and Simpson suggested that studies on tularemia treatment in the literature are generally observation-based or personal experience-based reports and that pinpointing the optimal treatment modalities is difficult. They concluded that randomized controlled studies are needed (Hepburn and Simpson, 2008)). In our study, seven patients were administered doxycycline (oral), four were given ciprofloxacin (parenteral-oral), and two were given streptomycin for 10 days (parenteral). No complications were encountered during any of the treatments. The small number of our patients and the retrospective nature of our study are the most important limitations of our study. In conclusion, the oropharyngeal form is the most commonly observed type of tularemia in our country. In regions where tularemia is epidemic, its diagnosis should be kept in mind as a differential diagnosis in patients who have a recent tonsillopharyngitis history that did not respond to empirical treatments, and in patients admitted to otorhinolaryngology outpatient clinics with a neck mass complaint

\section{References}

1. Atmaca, S., Leblebicioğlu, H., Ünal, R., Tekat, A., Şeşen, T., Koyuncu, M., Çakı1l, B., Ünal, A. 2005. Samsun ve çevresinde görülen tularemi olguları. KBB-Forum. 4, 171-172.

2. Barut, S., Cetin, I. 2009. A tularemia outbreak in an extended family in Tokat Province, Turkey: observing the attack rate of tularemia. Int. J. Infect. Dis.13, 745-748.

3. Ellis, J., Oyston, P.C., Green, M., Titball, R.W. 2002. Tularemia. Clin. Microbiol. Rev. 15, 631-646.

4. Helvacı, S., Gedikoğlu, S., Akalın, H., Oral, H.B. 2000. Tularemia in Bursa, Tukey: 205 cases in ten years. Eur.J.Epidemol. 16, 271276.

5. Hepburn, M. J., Simpson, A. J. 2008. Tularemia: current diagnosis and treatment options. Expert. Rev. Anti. Infect. Ther.6, 231-240.

6. K1lıc, S. 2010. Francisella tularensis ve Türkiye'de tularemia epidemiyolojisine genel bir bakış. Flora. 15, 37-58.

7. Kılıç, S., Yeşilyurt, M. 2011. Tularemi güncel tedavi seçeneklerine genel bir bakış. Klimik. Dergisi. 24, 2-10.

8. Lindquist, D., Chu, C.M., Probert, S.W. 2007. Francisella and Brucella. 9th ed. In: Murray PR, Barron EJ, Jorgensen JH, Landry ML, Pfaller MA, eds. Manual of Clinical Microbiology. ASM Press, Washington, 815-834.

9. Meric, M., Sayan, M., Willke, A., Gedikoglu, S. 2008. A small water-borne tularemia outbreak. Mikrobiyol. Bul. 42, 49-59.

10. Ozel, G., Arslan, I.B., Yesilyurt, M., Celebi, B., Kilic, S. 2010. An oropharyngeal tularemia case diagnosed by the isolation of Francisella tularensis on human blood agar. Mikrobiyol. Bul. 44, 657-663.

11. Sencan, I., Sahin, I., Kaya, D., Öksüz, S., Ozdemir, D., Karabay, O. 2009. An outbreak of oropharyngeal tularemia with cervical adenopathy predominantly in the left side. Yonsei. Med. J. 50, 5054.

12. Tarnvik, A., Chu, M. C. 2007. New approaches to diagnosis and therapy of tularemia. Ann. N. Y. Acad. Sci.1105, 378-404.

13. Willke, A. 2006. Tularemi. Ankem. Dergisi. 20, 222-226.

14. Word Health Organization (WHO), 2007. WHO guidelines on tularaemia. WHO Press,France. 